\title{
Brand Communication Through Inclusivity: The Perspective of First-Generation Americans
}

\author{
Caryn Pang, Kelcie Slaton and Te-Lin (Doreen) Chung \\ Iowa State University, USA
}

\section{Significance/Innovation of the Concept}

Retail brands use brand imagery and advertisements (i.e., brand communication) to connect and communicate with their target market and, in turn, promote sales of their products or services. Brand communication from all types of media has the power to influence consumers, as well as, inform, educate, and motivate them. However, as Lee, Elahee, and Acevedo (2004) concluded, consumers interpret these messages based on their own personal experiences, background, and culture. Among these factors, culture particularly has one of the most profound impact on how we receive, store, and make decisions (Hill, 2002; Kale, 1991). Each culture encompasses its own unique principles (Kalliny, 2010) and there is a variance on how messages from retail brands are perceived.

When expanding, many retail brands target new consumer groups as they would their traditional consumer base. However, this can be an ineffective strategy. For example, in 2017, Nike entered a new market segment focused on inclusivity, empowerment, and elevating female athletes with the Pro Nike Hijab. The premise of creating the hijab was aligned with Nike's mission, which is to serve all athletes (Diaz, 2017). The design and development of the pro hijab

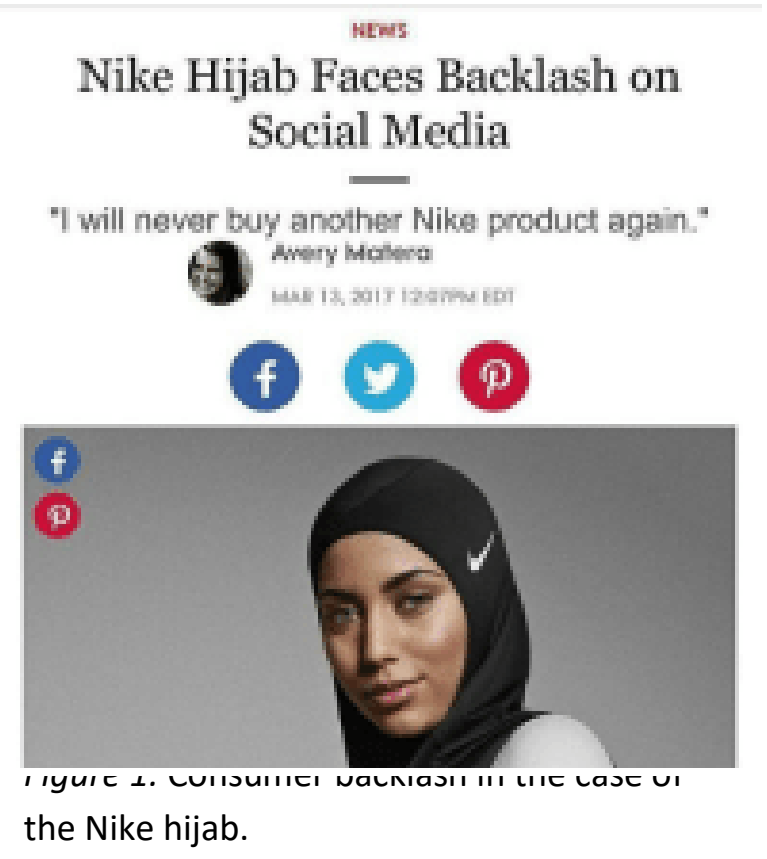

took on different phases, as well as, incorporating feedback from top hijab wearing athletes (Diaz, 2017). Additionally, the creation of the pro hijab was also a business strategy for Nike to fill a white space. Nike's market research estimated that their hijab could potentially reach 800 million people globally, and during this time frame the athleisure market was already valued at $\$ 97$ billion (Sergen, 2017).

The opening statement of Nike's global hijab television advertisement was provocative and implying to go "against the norm" (Think Marketing, 2017). As the advertisement continues, there are different scenes of females defying cultural norms, such as skateboarding down a street in the Middle East. Nike would gain almost 1 million views versus their forecast of only 26 thousand views. Hind Rasheed, Nike's

Published under a Creative Commons Attribution License (https://creativecommons.org/licenses/by/4.0/), which permits unrestricted use, distribution, and reproduction in any medium, provided the original work is properly cited.

ITAA Proceedings, \#76 - https://itaaonline.org 
Communication Manager in Dubai, commented that the focus of the TV advertisement was to inspire and encourage (Think Marketing, 2017). Although the brand images can be considered progressive, backlash did occur by the consumers that Nike targets. Consumers expressed that the sport hijab by Nike tolerates the subjugation of women (Spector 2017), did not display cultural dexterity, and indicated their misunderstanding of habits and cultural norms (Banks, 2017) (Figure 1). Nike marketed to these consumers based on prominent values of the American culture and did not consider some of the values of their ancestral culture creating negative word of mouth.

According to Hill (2002), brands are better received if they are perceived in line with the culture of their targeted market segment. Ghosh, Ghosh, and Ghosh (2016) conclude that the performance of a brand establishing in a new market is determined by the value of that brand and how it aligns with the consumer in that market. To create a connection with that consumer, the brand must incorporate the offerings per that culture. These offerings could vary from product, services, or being aligned to the brand from a consumer's perspective. The findings of both studies of Hill (2002) and Ghosh et al. (2016) showed the importance of integrating culture into the brand. The studies, however, did not investigate how cultural awareness of brands affects customer emotions and responses to the brand and its communication to the consumer. Therefore, the purpose of this conceptual paper is to investigate how retail brands communicate through images and advertisements particularly to first-generation Americans, as it pertains to cultural knowledge from the retailer. The authors choose to focus on first-generation Americans as this group of consumers are a unique market segment because they are tied to their ancestral culture but have also acculturated to American culture and social norms; thus, it is proposed that retailers need to thoroughly understand their values and beliefs to effectively market their offering to these consumers.

\section{Synthesis of Relevant Facts, Data and Literature}

First-generation Americans are defined as a person with immigrant parents. Researchers conclude that first generation Americans are conflicted between their ancestral culture and adopted culture (Lee et al., 2017). It can be inferred that first-generation Americans have combined both cultures to create a new culture for themselves. There are 44.5 million firstgeneration Americans estimated in 2017. This is a 1.8\% increase from the previous year (Lang \& Torbati, 2018). Retail brands need to refine existing branding strategies in order to attract and cultivate this group of consumers. Retailers can no longer implement their existing strategies with this growing market segment. Therefore, as this segment of the market continues to grow retail brands need to take a harder look at the targeted demographic by focusing on the attributes of first-generation Americans.

After a thorough review of the literature, it is concluded that there is minimal research conducted on first-generation Americans as most of the research focuses on a particular ethnic group that has immigrated into the United States such as, Asian and Hispanic Americans. Therefore, the authors feel strongly that this concept on first-generation Americans can help retailers and fashion brands recognize the need to create advertisements and brand images that

Published under a Creative Commons Attribution License (https://creativecommons.org/licenses/by/4.0/), which permits unrestricted use, distribution, and reproduction in any medium, provided the original work is properly cited.

ITAA Proceedings, \#76 - https://itaaonline.org 
are inclusive to this cohort of consumers. One related study by Lee, Elahee, and Acevedo (2006) explored cultural identity and advertisements as it pertained to first-generation Americans. Particularly, the authors investigated the meanings of advertisements within mass media and the impact it had on cultural identity. The authors found contradictory cultural messages received from media, society, acquaintances; thus, creating tension for first-generation Americans. Furthermore, the participants vehemently complained about negative stereotyping of immigrants in mass media. The finding from Lee et al. (2006) focused on how the advertisements contributed to the participant's identity, not the overall consumer behavior as presented by the authors of this conceptual paper; thus, a justification for further investigation into this phenomenon.

\section{Proposal for Future Action}

The purpose of this conceptual paper is to investigate how fashion brands can create a more inclusive experience for first-generation Americans with a more in-depth study of culture as it pertains to brand images, social representations, advertisements, and how it effects their consumer behavior. The next step is to gather data qualitatively to explore this phenomenon in depth and investigate the fashion imagery being shown to customers. Fashion brands and retailers may not have the deep cultural knowledge to fully utilize cultural norms which would have a positive impact on consumption and financial sales. Therefore, after having a conversation with these consumers, the study's findings would have an impact on how fashion brands could provide a more inclusive experience for first-generation Americans through their marketing communication.

Page 3 of 4

(c) 2019 The author(s). Published under a Creative Commons Attribution License (https://creativecommons.org/licenses/by/4.0/), which permits unrestricted use, distribution, and reproduction in any medium, provided the original work is properly cited.

ITAA Proceedings, \#76 - https://itaaonline.org 


\section{References}

Banks, B. (2017, March). Why Nike's pro hijab is more than just politics, Fortune. Retrieved from http://fortune.com/2017/03/11/nike-sports-hijab/.

Diaz, C. (2017, March). Brands support of Muslim athlete's now extends to products. Ad Age, Retrieved from https://adage.com/creativity/work/nike-pro-hijab/51224

Ghosh, M., Ghosh, A., \& Ghosh, M. (2016). Impact and influence of culture on brands in Indian market. Journal of Business and Management, 18(7), 54-60.

Hill, C. (2002). International Business, 3rd ed., McGraw Hill, Boston, MA.

Kale, S. (1991). Culture specific marketing communications: An analytical approach. International Marketing, 8(2), 18-30.

Kalliny, M. (2010). Are they really different from us? A comparison of Arab and American Newspaper Advertising. Journal of Current Issues and Research Advertising 32(1), 95108.

Lang, C. (2017, February). This Nike commercial features women athletes in Hijabs. Time Magazine, Retrieved from http://time.com/4682139/nike-commercial-women-athleteshijabs/

Lang, J., \& Torbati, Y. (2018, September). US born foreign population swells to highest in over a century. Reuters, Retrieved from https://www.reuters.com/article/us-usa-immigrationdata/u-s-foreign-born-population-swells-to-highest-in-over-a-century-idUSKCN1LT2HZ

Lee, R., Elahee, M., Acevedo, C. (2004). Cultural identity of the first generation Americans: A qualitative study. RAI, Revista de Administracao, 1(2), 67-83.

Nike News. (2017, December). The Nike hijab pro goes global, Nike Inc. Retrieved from https://news.nike.com/news/nike-pro-hijab/. .

Sergen, E. (2017, April). Meet the women who inspired Nike to enter the hijab business, Fast Company, Retrieved from https://www.fastcompany.com/40407096/meet-the-muslimwoman-who-inspired-nike-to-enter-the-hijab-business

Spector, N. (2017). Nike's hijab prompts backlash, boycott and praise. NBC News. Retrieved from http://www.nbcnews.com/business/consumer/nike-s-hijab-prompts-backlashboycott-praise-n733171

What marketers can learn from Nike pro hijab collection for female Muslim athletes (2017, March). Think Marketing Magazine. Retrieved from https://thinkmarketingmagazine.com/marketers-can-learn-nike-pro-hijab-collectionfemale-muslim-athletes/

Published under a Creative Commons Attribution License (https://creativecommons.org/licenses/by/4.0/), which permits unrestricted use, distribution, and reproduction in any medium, provided the original work is properly cited.

ITAA Proceedings, \#76 - https://itaaonline.org 